\title{
RETRACTED ARTICLE: Expression of a bacterial chitinase (ChiB) gene enhances resistance against E. polygoni induced powdery mildew disease in the transgenic Black gram (Vigna mungo L.) (cv. T9)
}

\author{
D. K. Das ${ }^{1}$
}

Received: 13 September 2015 / Revised: 13 January 2016 / Accepted: 28 January 2016 / Published online: 5 March 2016

(C) Prof. H.S. Srivastava Foundation for Science and Society 2016

The editors retract this article published at Online First, due to the author's unethical inclusion of all the figures and tables, as well as paraphrased text from his previously published research articles listed below:

1. Das, Dilip Kumar, Mrinalini Bhagat, and Sangeeta Shree. "Agrobacterium Mediated Transformation of Vigna mungo (L.) Hepper with Cry1Ac Gene for Insect Resistance." American Journal of Plant Sciences 7.02 (2016): 316.

2. Das, Dilip K., N. Shiva Prakash, and Neera Bhalla-Sarin. "An efficient regeneration system of black gram (Vigna mungo L.) through organogenesis." Plant Science 134.2 (1998): 199-206.

3. Das, Dilip K., et al. "Improved method of regeneration of black gram (Vigna mungo L.) through liquid culture." In Vitro Cellular \& Developmental Biology-Plant 38.5 (2002): 456-459.
4. Das, D. K., and A. Rahman. "Expression of a rice chitinase gene enhances antifungal response in transgenic litchi (cv. Bedana)." Plant Cell, Tissue and Organ Culture (PCTOC) 109.2 (2012): 315-325.

5. Das, D. K., and A. Rahman. "Expression of a rice chitinase gene (ChiB) enhances antifungal response in transgenic litchi (cv. Bedana)." Current Trends in Biotechnology and Pharmacy 4.3 (2010): 820-833.

The editors regret that this scientific misconduct escaped the evaluation processes of the journal and thank the complainants and pubpeer for bringing it to their notice. The reviewers of the manuscript and the employer of the author have been alerted of the misconduct.

The online version of this article contains the full text of the retracted article as electronic supplementary material.

D. K. Das

dilipdas1@live.com

Post Graduate Department of Biotechnology, T.M.Bhagalpur University, Bhagalpur 812007, India 